\title{
The effect of social media on travel planning process by Chinese tourists: the way forward to tourism futures
}

\author{
Yuke Yuan, Chung-Shing Chan, Sarah Eichelberger, Hang Ma and Birgit Pikkemaat
}

\begin{abstract}
Purpose - This paper investigates the usage and trust of Chinese social media in the travel planning process (pre-trip, during-trip and post-trip) of Chinese tourists.

Design/methodology/approach - Through a combination of structured online survey ( $\mathrm{n}=406)$ and followup interviews, the research identifies the diversification of the demand-and-supply patterns of social media users in China, as well as the allocation of functions of social media as tools before, during and after travel.

Findings - Social media users are diverse in terms of their adoption of social media, use behaviour and scope; the levels of trust and influence; and their ultimate travel decisions and actions. Correlations between the level of trust, influence of social media and the intended changes in travel decisions are observed. Destination marketers and tourism industries should observe and adapt to the needs of social media users and potential tourist markets by understanding more about user segmentation between platforms or apps and conducting marketing campaigns on social media platforms to attract a higher number of visitors.

Research limitations/implications - This paper demonstrated the case of social media usage in mainland China, which has been regarded as one of the fastest growing and influential tourist-generating markets and social media expansions in the world. This study further addressed the knowledge gap by correlating social media usage and travel planning process of Chinese tourists. The research findings suggested diversification of the demand-and-supply pattern of social media users in China, as well as the use of social media as tools before, during and after travel. Users were diversified in terms of their adoption of social media, use behaviour, scope, the levels of trust, influence and the ultimate travel decisions.

Practical implications - Destination marketing organizations should note that some overseas social media platforms that are not accessible in China like TripAdvisor, Yelp, Facebook and Instagram are still valued by some Chinese tourists, especially during-trip period in journeys to Western countries. Some tactics for specific user segments should be carefully observed. When promoting specific tourism products to Chinese tourists, it is necessary to understand the user segmentation between platforms or apps.

Originality/value - Social media is a powerful tool for tourism development and sustainability in creating smart tourists and destinations worldwide. In China, the use of social media has stimulated the development of both information and communication technology and tourism.
\end{abstract}

Keywords Information and communication technology (ICT), Outbound tourist market, Smart destinations, Travel planning process, User-generated content

Paper type Research paper

\section{Introduction}

In the era of information and communication technology (ICT) and social media, the Internet has evolved from a broadcast medium into an open platform, which allows users to become "media" themselves, giving them the power to search, organize, share, annotate and contribute content in a collaborative way (Parra-López et al., 2011). As the key industry and driver for economic growth in many cities, tourism has also been greatly affected by the expanding use of social media (Amaro et al. , 2016; Choe et al. , 2017; Chong et al. , 2018; Gretzel, 2018; Yoo et al., 2011; Zarezadeh et al.,
(Information about the authors can be found at the end of this article.)

Received 25 April 2021 Revised 18 October 2021

3 January 2022

13 January 2022

Accepted 9 February 2022

(C) Yuke Yuan, Chung-Shing Chan, Sarah Eichelberger, Hang $\mathrm{Ma}$ and Birgit Pikkemaat.

Published in Journal of Tourism Futures. Published by Emerald Publishing Limited. This article is published under the Creative Commons Attribution (CC BY 4.0) licence. Anyone may reproduce, distribute, translate and create derivative works of this article (for both commercial and non-

commercial purposes), subject to full attribution to the original publication and authors. The full terms of this licence may be seen at http://creativecommons.org/ licences/by/4.0/legalcode. 
2018). Social media has the ability to facilitate the operation of smart destinations and industries in the context of tourism-related ICT development and management.

Today, cities compete against each other as urban destinations to ensure economic sustainability in tourism because of growing mobility of people and capital (Dinnie, 2011). From a marketing perspective, social media is regarded as an important tool for destination promotion by organizations both in the public sector such as destination marketing organizations (DMOs) and tourism businesses (Ali and Frew, 2010; Chan and Guillet, 2011; Munar, 2011; Tang et al., 2017). Practitioners have reaffirmed the potential of social media to provide opportunities for product or service distribution and promotion (Akehurst and Akehurst, 2009). Social media also plays a crucial function in creating an interactive and mutual relationship between destinations and tourists, enabling governments, DMOs and tourism industries to understand their markets and adjust business strategies (Noone et al., 2011).

From the tourist perspective, social media has largely changed the way tourists make their travel plans and select destinations (Buhalis and Law, 2008; Gretzel, 2018). On the one hand, user-generated content (UGC) on social media has been considered an important and credible source of information (Filieri et al., 2015; Lam et al., 2020; Luo and Zhai, 2017; Parka and Nicolau, 2015; Qi and Chen, 2019; Xiang and Gretzel, 2010; Xiang et al., 2017; Zarezadeh et al., 2018). On the other hand, social media platforms allow tourists to develop networks and share travel experiences, which in turn influences travel decisions of other users (Choe et al., 2017; Noone et al., 2011). Moreover, social networks promote sustainable development in many ways (Sobhanifard and Vaeysi, 2020), for example, by encouraging participatory, improving expectation, pro-environmental behaviour and helping users search for diverse product and service information (Dinan and Sargeant, 2000; Han et al., 2018; Sarkar and George, 2018; Narangajavana et al., 2017).

In recent years, China has become one of the world's largest outbound tourist markets for cities (CTA and Ctrip, 2017). China has also experienced a rapid expansion of ICT and social media within the past decade. In 2017, the number of Internet users in China reached 751 million, indicating a high level of Internet penetration (CNNIC, 2017). China's unique political and economic systems have formed a distinctive social media network that is completely different from that in other countries (Chiu et al., 2012; Chong et al., 2018; Ge and Gretzel, 2018; Luo and Zhai, 2017). It is necessary to provide more theoretical knowledge and empirical information about the growing use of social media in China.

Based on the aforementioned background, it is found that the role of social media in Chinese tourists' travel planning process remains insufficiently understood by scholars and practitioners (Chen, 2017; Ge and Gretzel, 2018; Shang, 2016; Shi, 2013). The level of trust on UGC and social media may influence tourists' behaviour (Lam et al., 2020; Munar and Jacobsen, 2013). Social media is a crucial part of the ICT infrastructure of smart urban destinations, and it can transform these destinations to a higher level of innovation and sustainability through the provision of technology-enhanced experiences to tourists (Alaei et al., 2019; Chan et al., 2019; Fuchs et al., 2014; Li et al., 2018; Pikkemaat et al., 2018, 2019).

This paper answers the following research questions: (1) How is social media used before, during and after travel? (2) How are tourists' travel plans influenced by social media? (3) How are various types of social media characterized by the level of trust, especially compared with traditional sources of information (such as official DMO websites, travel agents, mass media advertising, commercial operators and accommodation sites) and traditional word of mouth (WOM) in China? Specific concluding remarks are derived to discuss the policy and practical implications of these research findings to tourism development futures.

\section{Literature review}

\section{Social media in China}

Based on the concepts of Web 2.0 and UGC, Kaplan and Haenlein (2010) proposed that social media refers to "a group of Internet-based apps that build on the ideological and technological foundations of Web 2.0, and that allow the creation and exchange of user generated content" 
(p. 61). From a more generic perspective, Filo et al. (2015) defined social media as "new media technologies facilitating interactivity and co-creation that allow for the development and sharing of user-generated content among and between organizations and individuals" (p. 167). Obar and Wildman (2015) further reviewed the literature on social media and identified four unique dimensions, namely Web 2.0, UGC, creation and interaction. Based on these definitions, social media can be summarized as Web 2.0-based online platforms that enable and promote the users' independent creation and sharing of UGC.

However, contemporary literature demonstrates lack of unified classification systems for social media (Brandtzæg, 2010; Chong et al., 2018; Ge and Gretzel, 2018; Gretzel, 2018; Zarezadeh et al., 2018). Based on the theories in media research (social presence/media richness) and social process (self-presentation/self-disclosure), Kaplan and Haenlein (2010) categorized social media into six types according to their usage characteristics. The six types are collaborative projects, blogs, content communities, social networking sites, virtual game worlds and virtual social worlds. This classification has two dimensions. The first is the degree of social presence and the richness of the medium, which determines how people communicate and interact with each other on the Internet (Dao, 2015). The second dimension describes social media as a tool of self-presentation and self-disclosure, which involves impression management and public sharing of personal information (Goffman, 1959; Derlega and Grzelak, 1979). The Chinese social media platforms have been allocated into the classification with slight modification based on the degree of social presence or media richness. The medium level of self-presentation/self-disclosure was added for better understanding of the media characteristics as presented in Table 1 (Kaplan and Haenlein, 2010).

With respect to self-presentation and self-disclosure, microblogs, blogs and social networking sites are considered higher than commercial tourism communities, third-party tourism communities and tourism social networking. The former are popular platforms where Chinese people prefer to manage and disclose their personal information publicly. Microblogs and blogs are personal web pages where owners can post messages while the blog or forum followers can view, download and comment online (Dao, 2015; Ge and Gretzel, 2018). The latter are limited to specific tourism content domains. Social networking sites, for example, enable users to interconnect by creating personal profiles, inviting others to join their sites, accessing the profiles of the site owners,

\begin{tabular}{|c|c|c|c|}
\hline \multirow{2}{*}{$\begin{array}{l}\text { Self- } \\
\text { presentation/ } \\
\text { self-disclosure }\end{array}$} & \multicolumn{3}{|c|}{ Social presence/media richness } \\
\hline & Low & Medium & High \\
\hline High & - & $\begin{array}{l}\text { Microblogs and blogs (e.g. Sino } \\
\text { Weibo, Tencent Weibo) }\end{array}$ & $\begin{array}{l}\text { Social networking } \\
\text { sites (e.g. WeChat, } \\
\text { Q-zone, Renren, } \\
\text { Linkedln) }\end{array}$ \\
\hline Medium & $\begin{array}{l}\text { Commercial tourism } \\
\text { communities (e.g. Tuniu, } \\
\text { Qunar, Ctrip, Fliggy and } \\
\text { Lvmama) }\end{array}$ & $\begin{array}{l}\text { Third-party tourism communities } \\
\text { (including pure third-party } \\
\text { tourism communities website } \\
\text { and third-party tourism } \\
\text { communities in comprehensive } \\
\text { website) } \\
\text { (e.g. Qiongyou, Mafengwo, } \\
\text { Mofang, Douban, Zhihu, Tieba, } \\
\text { Tianya and Xiaohongshu) }\end{array}$ & $\begin{array}{l}\text { Tourism social } \\
\text { networking (e.g. } \\
\text { Jianren and Tuyou) }\end{array}$ \\
\hline Low & $\begin{array}{l}\text { Collaborative projects } \\
\text { (e.g. Baidu Baike and } \\
\text { Hudong Baike) }\end{array}$ & $\begin{array}{l}\text { Content communities (e.g. Dou } \\
\text { Yin, Meipai, Miaopai and Youku) }\end{array}$ & - \\
\hline
\end{tabular}

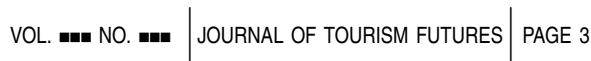


sharing information and sending instant messages (Dao, 2015; Kaplan and Haenlein, 2010). Finally, collaborative projects and content communities only allow limited self-disclosure. Collaborative projects encourage a joint effort and simultaneous content creation by participants (Kaplan and Haenlein, 2010), while content communities allow the sharing of media content such as videos, pictures and audio clips between users via a user-generated link (Dao, 2015).

\section{Travel planning process and social media}

Contemporary literature on the role of social media in the travel planning process such as Choe et al. (2017), Cox et al. (2009), Fotis et al. (2011) and Leung et al. (2013) tended to follow and combine the theories and models of generic consumer behaviour (Engel et al., 1973; Woodside and Lyonski, 1989) as illustrated in Figure 1.

The travel planning process consists of three key stages. In the pre-trip stage, potential travellers recognize their need for travel; they search for travel-related information and evaluate alternatives. During the trip, tourists also make specific purchase decisions. Finally, within the post-trip stage, tourists evaluate their trips by experience sharing through WOM or social media (Cox et al., 2009; Pan et al., 2007; Parra-López et al., 2011; Wang and Fesenmaier, 2004). Some of these activities might occur throughout the journey with ICT advancement. However, their most prominent time of taking the action or using specific a platform is still identifiable.

The role and impact of social media on different stages of the travel planning process have been widely investigated by researchers (Amaro et al., 2016; Choe et al., 2017; Ge and Gretzel, 2018; Haiyan, 2010; Xiang and Gretzel, 2010; Sparks and Browning, 2011). Some scholars have presented both similar and contradictory results. For instance, Cox et al. (2009) found that social media is predominantly used in the pre-trip stage for information search only but has a very limited usage during and after the trip. Contrastingly, Fotis et al. (2011) reported that social media was mainly used in the post-trip stage for experience sharing.

Since tourism products and services are costly with high involvement and well-differentiated in nature, potential travellers require extensive information search tactics to minimize the risk of making unwise decisions (Jeng and Fesenmaier, 2002; Sirakaya and Woodside, 2005). Therefore, some researchers have recognized the utmost importance of social media in searching for tourism-related information before a trip (Cox et al., 2009; Leung et al., 2013; Lo et al., 2011). Huang et al. (2010) agreed that obtaining travel information is the primary driving force for the use of

\section{Figure 1 Travel planning process}

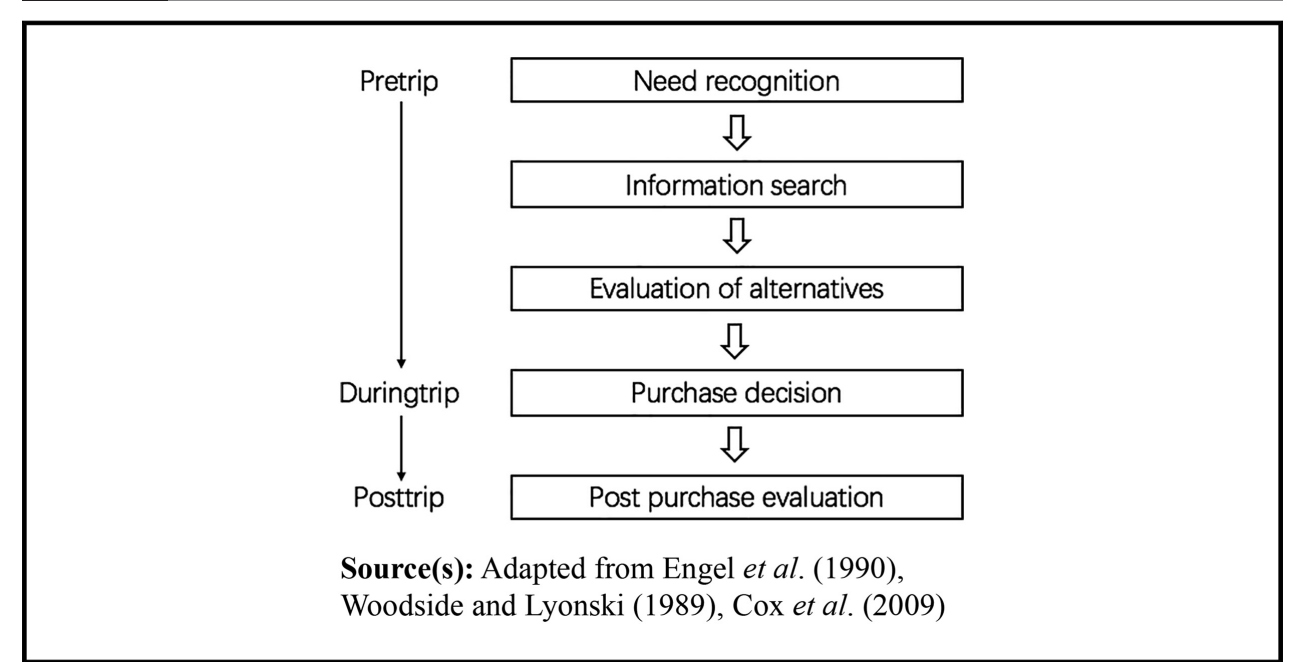

PAGE 4 |JOURNAL OF TOURISM FUTURES $\mid$ VOL. $\mathbf{m}$ NO. $\mathbf{m}$ 
social media. Moreover, Yoo and Gretzel (2010) noted that social media is more effective than other sources of information in providing comprehensive tourism-related knowledge.

The information search process is affected by the trustworthiness of travel-related UGC on social media (Lam et al., 2020; Leung et al., 2013; Munar and Jacobsen, 2013). UGC can be electronic word of mouth (e-WOM), which is considered a more important and trusted source for travel planning than commercial propaganda (Casaló et al., 2011; Murphy et al., 2007). Although UGC on social media is partly similar to traditional WOM, UGC is perceived to be less trustworthy than WOM (Leung et al., 2013; Mack et al., 2008). However, there have been some contrasting findings, for example, by Wasserman (2006), who found that only about one-fitth of surveyed respondents trusted information on social networks, while information provided on corporate websites was considered more trustworthy. Similarly, Cox et al. (2009) revealed that non-UGC sites such as DMO or airline websites were more highly trusted by users than general UGC, while third-party UGC-based sites were more autonomous and useful than weblogs or social networking sites. On the contrary, Fotis et al. (2011) noted that online information from other travellers was trusted more than official DMO websites or travel agents.

Studies have confirmed the influence of social media on travellers' planning and decision process (Fotis et al., 2011; Tussyadiah and Fesenmaier, 2009). Tussyadiah and Fesenmaier (2009) suggested that social media has had an increasing effect on destination awareness and choice set availability. Tussyadiah et al. (2011) verified that tourists' reviews or stories could enrich the overall knowledge about specific destinations, which in turn affects the intention to visit or revisit (Kirilenko et al., 2019; Munar and Jacobsen, 2013; Park et al., 2020). Fotis et al. (2011) revealed that the higher the perceived level of influence from social media on destination choice, the more likely potential travellers would change destination selection. Furthermore, Liu et al. (2020) recently identified a series of roles of social media in travel components and functions of need generator, supporter, guider and approver. Further research was proposed to include areas of on-site decision-making, technology adoption and the use of quantitative approach (Liu et al., 2020), which are bridged in the current study.

\section{Tourism futures and social media}

For Dinan and Sargeant (2000), social media provides contributions for people who are interested in smart and sustainable tourist destinations. In this sense, social media marketing offers tourism organizations opportunities to adopt a more sustainable approach by providing social marketing techniques and tools that have a potential impact on the sustainable behaviour of tourists (Dinan and Sarageant, 2000; Gretzel, 2018; Narangajavana et al., 2017). This is in line with the arguments of Han et al. (2018) on how to promote sustainable tourism by encouraging tourists to act with greater personal responsibility towards the destination and its environment. In this context, social media is defined as an essential channel for tourism information, especially with UGC that impacts environmental norms, the engagements in pro-environmental social media activities, as well as the development of pro-environmental online communities (Guzzo et al., 2013; Han et al., 2018).

Moscardo (2020) recently identifies three strong driving forces in Asian destinations supporting a paradigm shift in tourism futures, namely building on the experiential approach to tourism, the rise of mobile social media, UGC and gamification. This trend was also highlighted by Jamal and Budke (2020) in response to the global pandemic over the past year. Furthermore, Boley et al. (2013) identify a potential relationship between sustainable tourism and social media users. They observed that the use of social media promotes and influences the purchase of local-produced souvenirs by visitors and thus encouraging local community-based tourism development (Boley et al., 2013).

Although the role of social media in travellers' planning process has been widely discussed, national tourism markets are different in many aspects including how potential tourists react to the effect of social media (Ge and Gretzel, 2018; Zarezadeh et al., 2018). Fotis et al. (2011) therefore recommended further research about specific countries. Following the increasing popularity of 
social media and the expanding population of tourism consumers, there is a knowledge gap of investigating the role and impacts of social media on travellers' planning processes in China (Leung et al., 2013; Shang, 2016; Shi, 2013).

In China, a country with rapid and vigorous social media development, research connecting social media and travel planning process is still developing (Amaro et al., 2016; Chen, 2017; Choe et al., 2017; Ge and Gretzel, 2018; Haiyan, 2010; Kristensen, 2013; Shang, 2016; Shi, 2013). Most of these studies focussed on identifying factors such as characteristics of information, marketing methods and attitudes towards social media (Pabel and Prideaux, 2016; Shi, 2013; Shang, 2016; Chen, 2017) rather than linking social media and tourism futures (Fotis et al., 2011; Gretzel et al., 2008; Sobhanifard and Vaeysi, 2020). Except in the perspectives of tourism industries (e.g. Guillet et al., 2016) and outsiders from other countries (Li and Wang, 2011), and online marketing (e.g. Haiyan, 2010; Kristensen, 2013), there is an apparent knowledge gap in China regarding an explicit connection between social media usage (trustworthiness of information, influence of social media and motivation of travel experience sharing) and the implications to future tourism development in China and its various tourism resources and local destinations. Bridging this knowledge gap will provide more opportunities for destination innovation and transformation (Chan et al., 2019; Pikkemaat et al., 2018, 2019; Tiziana et al., 2013; Yoo et al., 2011). The future and sustainability of tourism requires more theoretical understanding of tourist market behaviour and reactions to supply-side factors in destinations (Dinan and Sargeant, 2000; Sarkar and George, 2018).

\section{Methodology}

This research adopted a mixed-method approach based on online questionnaire-based survey (Cox et al., 2009; Fotis et al., 2011) and interviews. The bilingual (Chinese and English) questionnaire measured, first, the social media use behaviour by the respondents, in terms of choice of destination, attractions, accommodation and transportation (Carifio and Perla, 2007). The second section detected several aspects of pre-trip, during-the-trip and post-trip stages of the travel process, including frequency of social media use, the trustworthiness of different kinds of social media, the level of influence and the likelihood of making changes to travel plans (Carifio and Perla, 2007; Cox et al., 2009; Fotis et al., 2011; Munar and Jacobsen, 2013). Finally, sociodemographic characteristics of the respondents were requested. The variables were measured by a seven-point Likert scale.

Convenience sampling was used for the survey due to the difficulty in covering a large sampling frame from China and randomizing respondent selection. Online questionnaire was designed and posted to the key Chinese social media platforms from low to high social richness shown in Table 1 if a publicly accessible platform is available for posting the survey link (which include Sino Weibo, Tencent Weibo, Qiongyou, Mafengwo, Zhihu, Tieba, Tianya, Xiaohongshu, WeChat, Q-zone and Renren). Data were collected in April and May 2018. Finally, a total of 453 questionnaires were completed with 406 deemed valid for further analysis, reaching a validity rate of $89.6 \%$. Statistical application provided descriptive statistics and a series of analysis including independent-sample $t$-test, correlation and factor analysis to perform inter-group comparison and verify the underlying factors of purposes of social media use.

Follow-up semi-structured in-depth interviews were conducted to further examine the Chinese tourists' perception, rationale and experiences in using social media in the travel process (Whiting, 2008). Since the interviews aimed to identify the views of the survey respondents, the potential interviewees were selected through invitations from the online survey, and voluntary sampling approach was adopted in this case. Upon a round of invitations from the survey sample, seven volunteers agreed to participate in the online interview. The interview questions were mainly derived from the questionnaire content (Cox et al., 2009; Fotis et al., 2011), but this part of the analysis deepens the discussion of relevant topics including previous travel experiences, selfreported social media use behaviour, reasons determining trustworthiness and influences of different applications of social media. Interpretative and thematic analyses were used to extract the 
ideas of the responses from this qualitative part of the result. The validity and reliability of the data and information collected from both survey and interviews are confirmed through multi-staged validation and verification process.

\section{Results}

\section{Profiles of respondents}

Table 2 presents the profiles of survey sampled respondents and Table 3 shows the profiles of interview participants. From the data, the survey respondents show the following characteristics: balanced gender distribution, a majority of younger age group ranged between 18 and 25 (67.5\%), postgraduate education (46.3\%) and an annual personal income of less than RMB29,999 (36.5\%). The selected interviewees were balanced in terms of gender and were mostly in their 20s and 30s. They had diverse occupations, income levels and varied outbound travel frequency due to own discretionary ability. Information saturation was detected by the interviewer and subsequently by researchers who conducted transcription and qualitative interpretation although the interviews were mainly voluntarily recruited.

\section{Table 2 Profile of survey participants}

\begin{tabular}{llrr}
\hline Variable & Category & Count & Percent (\%) \\
\hline Gender & Female & 204 & 50.3 \\
Age & Male & 202 & 49.8 \\
& Under 18 & 2 & 0.5 \\
& $18-25$ & 274 & 67.5 \\
& $26-35$ & 104 & 25.6 \\
Education level & $36-50$ & 21 & 5.2 \\
& Over 50 & 5 & 1.2 \\
& High school or below & 17 & 4.2 \\
Annual personal income (in RMB) & College graduated & 21 & 5.2 \\
& Bachelor's Degree & 180 & 44.3 \\
& Master's degree or above & 188 & 46.3 \\
& Less than 29,999 & 148 & 36.5 \\
& 30,000-49,999 & 58 & 14.3 \\
& 50,000-100,000 & 101 & 24.9 \\
& $100,000-200,000$ & 66 & 16.3 \\
& More than 200,000 & 33 & 8.0
\end{tabular}

\section{Table 3 Profile of interview participants}

\begin{tabular}{|c|c|c|c|c|c|c|}
\hline Code & Gender & Age & Education & Occupation & $\begin{array}{l}\text { Yearly income } \\
\text { (RMB) }\end{array}$ & $\begin{array}{l}\text { Outbound travel } \\
\text { frequency per year }\end{array}$ \\
\hline $\mathrm{R} 1$ & Female & 23 & Bachelor & $\begin{array}{l}\text { Secretary } \\
\text { Internet company }\end{array}$ & 108,000 & 10 \\
\hline $\mathrm{R} 2$ & Male & 24 & $\begin{array}{l}\text { Graduate } \\
\text { student }\end{array}$ & Intern in hospital & 48,000 & $1-2$ \\
\hline R3 & Female & 25 & $\begin{array}{l}\text { Graduate } \\
\text { student }\end{array}$ & $\begin{array}{l}\text { Unemployed } \\
\text { (Student) }\end{array}$ & $\begin{array}{l}60,000 \text { from } \\
\text { parents }\end{array}$ & $2-3$ \\
\hline $\mathrm{R} 4$ & Male & 26 & Master's & Engineer & 65,000 & 10 \\
\hline R5 & Male & 30 & Doctoral & $\begin{array}{l}\text { Artificial intelligence } \\
\text { engineer }\end{array}$ & 400,000 & $1-2$ \\
\hline R6 & Female & 35 & College & Bank manager & $1,000,000$ & $8-10$ \\
\hline $\mathrm{R} 7$ & Female & 45 & High school & $\begin{array}{l}\text { Unemployed } \\
\text { (Housewife) }\end{array}$ & $\begin{array}{l}36,000 \text { from } \\
\text { family }\end{array}$ & More than 10 \\
\hline
\end{tabular}




\section{Social media usage and behaviour}

A slightly larger proportion of survey respondents (29.8\%) travelled twice a year, followed by once per year (24.6\%) and $2-5$ times a year (24.4\%). In the travel process, many respondents (45.6\%) used social media $2-5$ times every day, more than $20 \%$ had used social media more than 10 times every day, but $5.7 \%$ never used social media in the process. Chi-square tests were performed to detect any socio-demographic characteristics determining frequency of social media usage. The findings confirmed that statistical significance was observed in gender $(\chi 2=11.92, p=0.018)$ and education ( $\chi 2=53.94, p=0.010$ ) but not age or income. Female users more likely to use social media more frequently, and the higher the education level, the higher the frequency of use.

The popularity of different types of social media showed that the top three social media types are WeChat (67.7\%), Sino Weibo (52.5\%) and Ctrip (48.0\%), which belong to the categories of social networking sites, microblogs, blogs and commercial tourism communities, respectively (Table 4). Interview results indicated that all interviewees predominantly used social networking sites and commercial tourism communities. Specifically, R5 expressed that some social media were not accessible in China, such as those of third-party tourism communities (e.g. TripAdvisor and Yelp): "before the trip, I usually search information in Google, Agoda and TripAdvisor and find the restaurant at the destination through Yelp".

\section{Functions of social media in the travel planning process}

Regarding the usage of social media, Table 5 presents the tourist ratings on different social media functions throughout the travel process, i.e. before, during and after travel. In the pre-trip stage, social media is used primarily to search for information about accommodation options (mean $=5.85$ ) and to screen options of attractions before departure (mean $=5.63)$. Within the during-the-trip stage, respondents largely used social media to locate information about specific attractions and leisure activities (mean $=5.57$ ) and to a lesser extent to communicate with friends

\begin{tabular}{|c|c|}
\hline Interviewee & Top three types of social media the interviewees used in travel \\
\hline \multirow[t]{3}{*}{$\mathrm{R} 1$} & CTC: Qunar, Ctrip \\
\hline & TTC: Mafengwo, Zhihu, Xiaohongshu \\
\hline & SNS: WeChat, Weibo \\
\hline \multirow[t]{3}{*}{$\mathrm{R} 2$} & CTC: Qunar, Ctrip \\
\hline & TTC: Dazhongdianping \\
\hline & SNS: WeChat, QQ \\
\hline \multirow[t]{4}{*}{ R3 } & CTC: Qunar, Ctrip, Flypig \\
\hline & TTC: Mafengwo, Qiongyou, Dazhongdianping \\
\hline & SNS: WeChat, Weibo, QQ \\
\hline & CP: Baidubaike \\
\hline \multirow[t]{3}{*}{ R4 } & CTC: Ctrip \\
\hline & TTC: Mafengwo \\
\hline & SNS: WeChat \\
\hline \multirow[t]{3}{*}{ R5 } & CTC: Lvmama, Flypig, Ctrip, Agoda \\
\hline & TTC: Mafengwo, Tripadviser, Yelp \\
\hline & SNS: Wechat \\
\hline \multirow[t]{3}{*}{ R6 } & CTC: Qunar, Ctrip, Feizhu \\
\hline & TTC: Mafengwo, Qiongyou, Dazhongdianping \\
\hline & SNS: WeChat \\
\hline \multirow[t]{2}{*}{$\mathrm{R} 7$} & CTC: Tuniu, Tongchenglvyou \\
\hline & SNS: WeChat, QQ \\
\hline
\end{tabular}


Table 5 Means and standard deviations of variables measuring social media use during the travel process $(n=406)$

\begin{tabular}{|c|c|c|c|c|c|c|c|c|c|}
\hline \multirow[b]{2}{*}{ Item } & \multicolumn{7}{|c|}{ Frequency and percent (\%) $(1=$ Never; $7=$ Every time $)$} & \multirow[b]{2}{*}{ Mean } & \multirow[b]{2}{*}{$S D$} \\
\hline & 1 & 2 & 3 & 4 & 5 & 6 & 7 & & \\
\hline \multicolumn{10}{|l|}{ Pre-trip (mean $=5.42)$} \\
\hline Search ideas about destination options & $\begin{array}{l}14 \\
3.4 \%\end{array}$ & $\begin{array}{l}37 \\
9.1 \%\end{array}$ & $\begin{array}{l}32 \\
7.9 \%\end{array}$ & $\begin{array}{l}65 \\
16.0 \%\end{array}$ & $\begin{array}{l}62 \\
15.3 \%\end{array}$ & $\begin{array}{l}111 \\
27.3 \%\end{array}$ & $\begin{array}{l}85 \\
20.9 \%\end{array}$ & 4.96 & 1.722 \\
\hline $\begin{array}{l}\text { Search information for screening choices of } \\
\text { destinations }\end{array}$ & $\begin{array}{l}6 \\
1.5 \%\end{array}$ & $\begin{array}{l}24 \\
5.9 \%\end{array}$ & $\begin{array}{l}28 \\
6.9 \%\end{array}$ & $\begin{array}{l}66 \\
16.3 \%\end{array}$ & $\begin{array}{l}59 \\
14.5 \%\end{array}$ & $\begin{array}{l}131 \\
32.3 \%\end{array}$ & $\begin{array}{l}92 \\
22.7 \%\end{array}$ & 5.24 & 1.544 \\
\hline Confirm good destination choices & $\begin{array}{l}7 \\
1.7 \%\end{array}$ & $\begin{array}{l}18 \\
4.4 \%\end{array}$ & $\begin{array}{l}20 \\
4.9 \%\end{array}$ & $\begin{array}{l}61 \\
15.0 \%\end{array}$ & $\begin{array}{l}58 \\
14.3 \%\end{array}$ & $\begin{array}{r}138 \\
34 \%\end{array}$ & $\begin{array}{l}104 \\
25.6 \%\end{array}$ & 5.40 & 1.494 \\
\hline Search information about accommodation & $\begin{array}{l}3 \\
0.7 \%\end{array}$ & $\begin{array}{l}10 \\
2.5 \%\end{array}$ & $\begin{array}{l}17 \\
4.2 \%\end{array}$ & $\begin{array}{l}30 \\
7.4 \%\end{array}$ & $\begin{array}{l}51 \\
12.6 \%\end{array}$ & $\begin{array}{l}137 \\
33.7 \%\end{array}$ & $\begin{array}{l}158 \\
38.9 \%\end{array}$ & 5.85 & 1.323 \\
\hline Search information to screen choices of attractions & $\begin{array}{l}3 \\
0.7 \%\end{array}$ & $\begin{array}{l}11 \\
2.7 \%\end{array}$ & $\begin{array}{l}14 \\
3.4 \%\end{array}$ & $\begin{array}{r}57 \\
14 \%\end{array}$ & $\begin{array}{l}60 \\
14.8 \%\end{array}$ & $\begin{array}{r}138 \\
34 \%\end{array}$ & $\begin{array}{l}123 \\
30.3 \%\end{array}$ & 5.63 & 1.344 \\
\hline \multicolumn{10}{|l|}{ During-trip (mean $=5.19)$} \\
\hline $\begin{array}{l}\text { Search information about specific attractions and } \\
\text { leisure activities }\end{array}$ & $\begin{array}{l}5 \\
1.2 \%\end{array}$ & $\begin{array}{l}10 \\
2.5 \%\end{array}$ & $\begin{array}{l}20 \\
4.9 \%\end{array}$ & $\begin{array}{l}51 \\
12.6 \%\end{array}$ & $\begin{array}{l}70 \\
17.2 \%\end{array}$ & $\begin{array}{l}129 \\
31.8 \%\end{array}$ & $\begin{array}{l}121 \\
29.8 \%\end{array}$ & 5.57 & 1.391 \\
\hline Communicate with friends and acquaintances & $\begin{array}{l}6 \\
1.5 \%\end{array}$ & 20 . $4 \%$ & $\begin{array}{l}25 \\
6.2 \%\end{array}$ & $\begin{array}{l}50 \\
12.3 \%\end{array}$ & $\begin{array}{l}66 \\
16.3 \%\end{array}$ & $\begin{array}{l}106 \\
26.1 \%\end{array}$ & $\begin{array}{l}133 \\
32.5 \%\end{array}$ & 5.46 & 1.553 \\
\hline Leisure purpose & $\begin{array}{l}4 \\
1.0 \%\end{array}$ & $\begin{array}{l}24 \\
5.9 \%\end{array}$ & $\begin{array}{l}41 \\
10.1 \%\end{array}$ & $\begin{array}{l}81 \\
20.0 \%\end{array}$ & $\begin{array}{l}62 \\
15.3 \%\end{array}$ & $\begin{array}{l}109 \\
26.8 \%\end{array}$ & $\begin{array}{l}85 \\
20.9 \%\end{array}$ & 5.07 & 1.549 \\
\hline Develop relationship with other travellers & $\begin{array}{l}24 \\
5.9 \%\end{array}$ & $\begin{array}{l}42 \\
10.3 \%\end{array}$ & $\begin{array}{l}41 \\
10.1 \%\end{array}$ & $\begin{array}{l}73 \\
18.0 \%\end{array}$ & $\begin{array}{l}65 \\
16.0 \%\end{array}$ & $\begin{array}{l}83 \\
20.4 \%\end{array}$ & $\begin{array}{l}78 \\
19.2 \%\end{array}$ & 4.66 & 1.824 \\
\hline \multicolumn{10}{|l|}{ Post-trip (mean $=4.95)$} \\
\hline $\begin{array}{l}\text { Share photos and videos with friends and other } \\
\text { travellers }\end{array}$ & $\begin{array}{l}15 \\
3.7 \%\end{array}$ & $\begin{array}{l}17 \\
4.2 \%\end{array}$ & $\begin{array}{l}18 \\
4.4 \%\end{array}$ & $\begin{array}{l}51 \\
12.6 \%\end{array}$ & $\begin{array}{l}60 \\
14.8 \%\end{array}$ & $\begin{array}{l}123 \\
30.3 \%\end{array}$ & $\begin{array}{l}122 \\
30.0 \%\end{array}$ & 5.42 & 1.615 \\
\hline $\begin{array}{l}\text { Provide comments and reviews about travel } \\
\text { experiences }\end{array}$ & $\begin{array}{l}22 \\
5.4 \%\end{array}$ & $\begin{array}{l}25 \\
6.2 \%\end{array}$ & $\begin{array}{l}35 \\
8.6 \%\end{array}$ & $\begin{array}{l}59 \\
14.5 \%\end{array}$ & $\begin{array}{l}68 \\
16.7 \%\end{array}$ & $\begin{array}{l}99 \\
24.4 \%\end{array}$ & $\begin{array}{l}98 \\
24.1 \%\end{array}$ & 5.01 & 1.769 \\
\hline Obtain ideas of inspiration for next trip & $\begin{array}{l}39 \\
9.6 \%\end{array}$ & $\begin{array}{l}33 \\
8.1 \%\end{array}$ & $\begin{array}{l}57 \\
14.0 \%\end{array}$ & $\begin{array}{l}81 \\
20.0 \%\end{array}$ & $\begin{array}{l}58 \\
14.3 \%\end{array}$ & $\begin{array}{l}63 \\
15.5 \%\end{array}$ & $\begin{array}{l}75 \\
18.5 \%\end{array}$ & 4.42 & 1.895 \\
\hline
\end{tabular}

and acquaintances (mean $=5.46$ ). The development of relationships with other travellers is regarded the least important by respondents (mean $=4.66$ ).

During the post-trip stage, social media was largely applied to share trip-related photos, videos and other materials with friends and other online users (mean $=5.42$ ) but was used to a lesser extent to provide comments and reviews about travel experiences (mean $=5.01$ ).

To understand the influences of social media on individual travel planning, principal component analysis (PCA) with varimax rotation was further conducted to examine the underlying driving factors determining the use of social media throughout the travel process (Table 6). The resultant analysis extracted two factors containing high factor loadings, which explain $61.5 \%$ of the total variance across twelve variables. Based on the nature of each factor, the first factor was labelled "search for information" (Cronbach's alpha $=0.900$; eigenvalue $=3.976$; variance explained $=33.146 \%$ ), which encompassed five pre-trip items and one during-trip item. These items determine the information about destinations and relevant travel options. The second factor was identified as sociability and entertainment (Cronbach's alpha $=0.833$; eigenvalue $=3.407$; variance explained $=28.391 \%$ ), which consisted of three during-the-trip and three post-trip items. These items were mainly related to inter-travellers' communications and future travel oriented.

Some interview responses further support the aforementioned observations. For instance, WeChat, a social networking site, was found to be important in pre-trip stage: "WeChat is important to my travel. Tourism destinations with photos that other people showed in moments of WeChat are very likely to be my next destination. WeChat can help me recognize my travel need" (R1). Third-party tourism communities such as Mafengwo and Qiongyou were mainly used to search for information about destinations and experiences posted by other tourists. Commercial 
Table 6 Factor analysis results of the travel planning process $(n=406)$

Factors and underlying elements

Factor 1: Search for information

Pre-trip: Search ideas about destination options

Pre-trip: Search information for screening choices of destinations

Pre-trip: Confirm good destination choices

Pre-trip: Search information about accommodation

Pre-trip: Search information to screen choices of attractions

During-the-trip: Search information about specific attractions and leisure activities

Factor 2: Sociability and entertainment

During-the-trip: Communicate with friends and acquaintances

During-the-trip: Leisure purpose

During-the-trip: Develop relationship with other travellers

After-trip: Share photos and videos with friends and other travellers

After-trip: Provide comments and reviews about travel experiences

After-trip: Obtain ideas of inspiration for next trip
Factor

loading

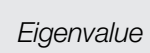

Variance explained

(\%)

Alpha

3.976

33.146

0.900

0.722

0.844

0.827

0.707

0.804

0.728

3.407

$28.391 \%$

0.833

0.700

0.551

0.763

0.789

0.577

Note(s): $\mathrm{KMO}=0.894$, Bartlett's test of sphericity $=2802.947$ at df 66 with a significance of $p=0.000$

tourism communities such as Qunar, C-trip and Flypig were used to evaluate cost-performance of transportation, hotels, admission tickets and other travel costs.

In the during-the-trip stage, third-party tourism communities like Yelp and Dazhongdianping were popular for searching information about nearby restaurants, attractions and for solving travelrelated problems although some interviewees also used WeChat in this stage for different purposes. R4 and R7, for example, used WeChat search engine for food, transportation and attractions, whereas R3 just used WeChat as an instant communication tool to seek local friends in the destination for recommendations. Finally, in the post-trip stage, all the interviewees mentioned social networking sites, particularly WeChat for experience sharing.

\section{Influence of social media on travel-related choices}

Comparing the choices of travel-related areas in Table 7, all four types of travel-related choices tend to be influenced by social media with mean scores of influences higher than 5 out of 7 . Specifically, social media had the strongest influence on accommodation choices (mean $=5.48$ ) and the least effect on destination selection (mean $=5.02$ ).

A round of one-sample $t$-test further identified that social media had a significantly greater influence on choice of accommodation than other travel-related areas. By taking the value of 5.48 (as an

Table 7 Influence of social media on travel-related choices $(n=406)$

\begin{tabular}{|c|c|c|c|c|c|c|c|c|c|c|c|}
\hline \multirow[b]{2}{*}{ Influence on choice of } & \multicolumn{7}{|c|}{ Level of influence (1 = no influence at all; 7 = extremely influential) } & \multirow[b]{2}{*}{ Mean } & \multirow[b]{2}{*}{$S D$} & \multirow[b]{2}{*}{ t-value } & \multirow[b]{2}{*}{$d f$} \\
\hline & 1 & 2 & 3 & 4 & 5 & 6 & 7 & & & & \\
\hline Accommodation & $\begin{array}{l}4 \\
1.0 \%\end{array}$ & $\begin{array}{l}6 \\
1.5 \%\end{array}$ & $\begin{array}{l}22 \\
5.4 \%\end{array}$ & $\begin{array}{l}34 \\
8.4 \%\end{array}$ & $\begin{array}{l}105 \\
25.9 \%\end{array}$ & $\begin{array}{l}165 \\
40.6 \%\end{array}$ & $\begin{array}{l}70 \\
17.2 \%\end{array}$ & 5.48 & 1.210 & $\begin{array}{l}\text { Test } \\
\text { value }=5.48\end{array}$ & \\
\hline Destination & $\begin{array}{l}15 \\
3.7 \%\end{array}$ & $\begin{array}{l}14 \\
3.4 \%\end{array}$ & $\begin{array}{l}27 \\
6.7 \%\end{array}$ & $\begin{array}{l}45 \\
11.1 \%\end{array}$ & $\begin{array}{l}133 \\
32.8 \%\end{array}$ & $\begin{array}{l}135 \\
33.3 \%\end{array}$ & $\begin{array}{l}37 \\
9.1 \%\end{array}$ & 5.02 & 1.722 & $-6.591^{\star \star}$ & 405 \\
\hline Attraction & $\begin{array}{l}9 \\
2.2 \%\end{array}$ & $\begin{array}{l}13 \\
3.2 \%\end{array}$ & $\begin{array}{l}18 \\
4.4 \%\end{array}$ & $\begin{array}{l}41 \\
10.1 \%\end{array}$ & $\begin{array}{l}102 \\
25.1 \%\end{array}$ & $\begin{array}{l}164 \\
40.4 \%\end{array}$ & $\begin{array}{l}59 \\
14.5 \%\end{array}$ & 5.32 & 1.544 & $-2.394^{*}$ & 405 \\
\hline Transportation & $\begin{array}{l}7 \\
1.7 \%\end{array}$ & $\begin{array}{l}14 \\
3.4 \%\end{array}$ & $\begin{array}{l}27 \\
6.7 \%\end{array}$ & $\begin{array}{l}43 \\
10.6 \%\end{array}$ & $\begin{array}{l}104 \\
25.6 \%\end{array}$ & $\begin{array}{l}165 \\
40.6 \%\end{array}$ & $\begin{array}{l}46 \\
11.3 \%\end{array}$ & 5.22 & 1.332 & $-3.909^{\star \star}$ & 405 \\
\hline
\end{tabular}

PAGE $10 \mid$ JOURNAL OF TOURISM FUTURES $\mid$ VOL. 
observed mean score of influence on accommodation), the mean scores of destination, attraction and transportation choices were examined. As shown in Table 7, the influence of social media on accommodation was significantly higher than that of destination ( $t=-6.591 ; p<0.001)$, attraction $(t=-2.394 ; p<0.000)$ or transportation ( $t=-3.909 ; p<0.001)$ accordingly. The negative $t$-values in the above analyses are due to the highest test values rather than any directional implication.

Pearson correlation analysis was performed to verify the relationship between the influence level of social media and the possibility of subsequent changes made to overall travel plan. The results in Table 8 show that all four pairs of correlation are statistically significant. These findings show that levels of influence on destination $(r=0.41, p<0.01)$, attractions $(r=0.41, p<0.01)$, accommodation $(r=0.31, p<0.01)$ and transportation $(r=0.26, p<0.01)$ all demonstrated a moderate degree of positive correlation with the change in travel plan (Dancey and Reidy, 2011).

Similarly, another round of Pearson correlation test identified a positive relationship between levels of trust of social media and the influence levels of the four travel-related choices, where correlation coefficients of 0.43 (destinations), 0.45 (attractions), 0.48 (accommodation) and 0.31 (transportation) were observed $(p<0.01)$. These correlations were largely in a moderate level (Dancey and Reidy, 2011). In short, the higher the level of trust on social media, the more likely that travel-related choices would be affected by social media, and consequently more frequent changes would be made to travel plans.

\section{Trustworthiness of social media in the travel planning process}

More research findings on the varied levels of trust across traditional sources of information and traditional WOM in China are examined. Regarding the degree of trust of social media (Table 9), the traditional WOM (mean $=5.42)$ triumphed over UGC (mean $=4.86)$ and other traditional sources of information (mean $=4.52$ ) such as DMOs and mass media. In particular, the information supplied by friends, relatives or other acquaintances was the most reliable (mean $=5.57$ ), whereas travel agents were the least trusted type of source.

In terms of UGC in different types of social media, third-party tourism communities (mean $=5.16$ ) appear to be the most trusted source of information, followed by microblogs and blogs (mean $=5.02$ ). However, collaborative projects had the lowest level of trust (mean $=4.50$ ). Independent-sample $t$-test verifies the inter-source differences between the three types of information. The results in Table 9 clearly showed that UGC in social media was significantly more trusted by respondents than traditional sources of information $(t=-7.31, p<0.05)$ but less trusted by respondents than traditional WOM $(t=12.51, p<0.05)$. Qualitative responses by some interviewees further showed that their preference for specific social media types was due to the presence of one-stop source of information: "compared with one-sided statement from friends and relatives, information on third-party tourism communities like Mafengwo is more comprehensive and is a reflection of current popular taste" (R1).

Similar comparison between the levels of trust in different types of UGC of social media is presented in Table 10 through one-sample $t$-test. The findings show that all other social media

Table 8 Correlation between social media and change in original travel plan $(n=406)$

\begin{tabular}{|c|c|c|c|c|}
\hline & \multicolumn{4}{|c|}{ Pearson correlation } \\
\hline & $\begin{array}{l}\text { Destination } \\
\text { choice }\end{array}$ & $\begin{array}{l}\text { Attraction } \\
\text { choice }\end{array}$ & $\begin{array}{l}\text { Accommodation } \\
\text { choice }\end{array}$ & $\begin{array}{l}\text { Transportation } \\
\text { choice }\end{array}$ \\
\hline Subsequent change in & $r=0.41$ & $r=0.41$ & $r=0.31$ & $r=0.26$ \\
\hline travel plan & $p<0.01$ & $p<0.01$ & $p<0.001$ & $p<0.01$ \\
\hline Trust in social media & $r=0.43$ & $r=0.45$ & $r=0.48$ & $r=0.31$ \\
\hline & $p<0.01$ & $p<0.01$ & $p<0.01$ & $p<0.01$ \\
\hline
\end{tabular}

VOL. m. NO. m. $\mid$ JOURNAL OF TOURISM FUTURES $\mid$ PAGE 11 
Table 9 Trustfulness in online social media sources versus other sources of travel information $(n=406)$

Frequency and percent (\%)

\begin{tabular}{|c|c|c|c|c|c|c|c|c|c|}
\hline \multirow[b]{2}{*}{ Item } & \multicolumn{7}{|c|}{$\begin{array}{c}\text { Frequency and percent (\%) } \\
\text { (1 = Strongly disagree; } 7 \text { = Strongly agree) }\end{array}$} & \multirow[b]{2}{*}{ Mean } & \multirow[b]{2}{*}{$S D$} \\
\hline & 1 & 2 & 3 & 4 & 5 & 6 & 7 & & \\
\hline \multicolumn{10}{|l|}{ UGC in social media (mean $=4.86)$} \\
\hline \multirow{2}{*}{$\begin{array}{l}\text { I trust information from travellers on microblogs } \\
\text { and blogs }\end{array}$} & 4 & 8 & 10 & 74 & 180 & 116 & 14 & \multirow[t]{2}{*}{5.02} & \multirow[t]{2}{*}{1.041} \\
\hline & $1.0 \%$ & $2.0 \%$ & $2.5 \%$ & $18.2 \%$ & $44.3 \%$ & $28.57 \%$ & $3.5 \%$ & & \\
\hline \multirow{2}{*}{$\begin{array}{l}\text { I trust information from travellers on social } \\
\text { networking sites }\end{array}$} & 3 & 11 & 15 & 76 & 167 & 121 & 13 & \multirow[t]{2}{*}{4.99} & \multirow[t]{2}{*}{1.126} \\
\hline & $0.7 \%$ & $2.7 \%$ & $3.7 \%$ & $18.7 \%$ & $41.1 \%$ & $29.8 \%$ & $3.2 \%$ & & \\
\hline \multirow{2}{*}{$\begin{array}{l}\text { I trust information from travellers on tourism social } \\
\text { networking }\end{array}$} & 3 & 14 & 20 & 98 & 164 & 95 & 12 & \multirow[t]{2}{*}{4.82} & \multirow[t]{2}{*}{1.190} \\
\hline & $0.7 \%$ & $3.5 \%$ & $4.9 \%$ & $24.1 \%$ & $40.4 \%$ & $23.4 \%$ & $3.0 \%$ & & \\
\hline \multirow{2}{*}{$\begin{array}{l}\text { I trust information from travellers on commercial } \\
\text { tourism communities }\end{array}$} & 2 & 12 & 18 & 105 & 166 & 92 & 11 & \multirow[t]{2}{*}{4.83} & \multirow[t]{2}{*}{1.088} \\
\hline & $0.5 \%$ & $3.0 \%$ & $4.4 \%$ & $25.9 \%$ & $40.9 \%$ & $22.7 \%$ & $2.7 \%$ & & \\
\hline \multirow{2}{*}{$\begin{array}{l}\text { I trust information from travellers on third-party } \\
\text { tourism communities }\end{array}$} & 1 & 12 & 13 & 66 & 146 & 139 & 29 & \multirow[t]{2}{*}{5.16} & \multirow[t]{2}{*}{1.201} \\
\hline & $0.3 \%$ & $3.0 \%$ & $3.2 \%$ & $16.3 \%$ & $36.0 \%$ & $34.2 \%$ & $7.1 \%$ & & \\
\hline \multirow{4}{*}{$\begin{array}{l}\text { I trust information from travellers on content } \\
\text { communities } \\
\text { I trust information from travellers on collaborative } \\
\text { projects }\end{array}$} & 7 & 13 & 31 & 110 & 136 & 98 & 11 & \multirow[t]{2}{*}{4.71} & \multirow[t]{2}{*}{1.408} \\
\hline & $1.7 \%$ & $3.2 \%$ & $7.6 \%$ & $27.1 \%$ & $33.5 \%$ & $24.1 \%$ & $2.7 \%$ & & \\
\hline & 10 & 25 & 38 & 114 & 128 & 79 & 12 & 4.50 & 1.673 \\
\hline & $2.5 \%$ & $6.2 \%$ & $9.4 \%$ & $28.1 \%$ & $31.5 \%$ & $19.5 \%$ & $3.0 \%$ & & \\
\hline \multicolumn{10}{|c|}{ Traditional WOM $($ mean $=5.42 ; t=12.513 ; p<0.05)$} \\
\hline I trust information from friends, relatives or other & 0 & 3 & 7 & 39 & 121 & 180 & 56 & \multirow[t]{2}{*}{5.57} & \multirow[t]{2}{*}{0.908} \\
\hline acquaintances & $0.0 \%$ & $0.7 \%$ & $17 \%$ & $9.6 \%$ & $29.8 \%$ & $44.3 \%$ & $13.8 \%$ & & \\
\hline \multirow[t]{2}{*}{ I trust information that people tell me face-to-face } & 1 & 8 & 12 & 65 & 129 & 155 & 36 & \multirow[t]{2}{*}{5.27} & \multirow[t]{2}{*}{1.161} \\
\hline & $0.3 \%$ & $2.0 \%$ & $3.0 \%$ & $16.0 \%$ & $31.8 \%$ & $38.2 \%$ & $8.9 \%$ & & \\
\hline Traditional source of information $($ mean $=4.52 ; t$ & -7.310 & $p<0.05)$ & & & & & & & \\
\hline I trust information provided on state tourism & 2 & 11 & 32 & 73 & 102 & 130 & 56 & 5.16 & 1.669 \\
\hline websites & $0.5 \%$ & $2.7 \%$ & $7.9 \%$ & $18.0 \%$ & $25.1 \%$ & $32 \%$ & $13.8 \%$ & & \\
\hline I trust information provided by travel agents & 17 & 30 & 73 & 126 & 105 & 49 & 6 & 4.09 & 1.723 \\
\hline & $4.2 \%$ & $7.4 \%$ & $18.0 \%$ & $31.0 \%$ & $25.9 \%$ & & $1.5 \%$ & & \\
\hline I trust information from commercial operators & 9 & 16 & 58 & 132 & 130 & 55 & 6 & 4.35 & 1.378 \\
\hline and/or accommodation sites & $2.2 \%$ & $3.9 \%$ & $14.3 \%$ & $32.5 \%$ & $32.0 \%$ & $13.6 \%$ & $1.5 \%$ & & \\
\hline I trust information received through mass media & 5 & 18 & 48 & 126 & 142 & 58 & 9 & 4.46 & 1.320 \\
\hline advertising, such as television, newspaper & $1.2 \%$ & $4.4 \%$ & $11.8 \%$ & $31.0 \%$ & $35.0 \%$ & $14.3 \%$ & $2.2 \%$ & & \\
\hline
\end{tabular}

Table 10 Comparison between the levels of trust of the types of UGC of social media $(n=406)$

\begin{tabular}{|c|c|c|c|c|}
\hline \multirow[b]{2}{*}{ UGC from third-party tourism communities } & \multirow{2}{*}{$\begin{array}{c}\text { Mean }{ }^{* *} \text { for all respondents } \\
N=406 \text { (S.D.) }\end{array}$} & \multicolumn{3}{|c|}{ Test value $=5.16^{*}$} \\
\hline & & t value & $d f$ & $p$ \\
\hline Microblogs and blogs & $5.02(1.020)$ & -2.673 & 405 & $0.01^{\star \star \star}$ \\
\hline Social networking sites & $4.99(1.061)$ & -3.226 & 405 & $0.00^{\star \star \star}$ \\
\hline Tourism social networking & $4.82(1.091)$ & -6.277 & 405 & $0.00^{\star \star \star}$ \\
\hline Commercial tourism communities & $4.83(1.043)$ & -6.469 & 405 & $0.00^{\star \star \star}$ \\
\hline Content communities & $4.71(1.186)$ & -7.065 & 405 & $0.00^{\star \star \star}$ \\
\hline Collaborative projects & $4.50(1.293)$ & -10.244 & 405 & $0.00^{\star \star \star}$ \\
\hline
\end{tabular}

Note(s): UGC, user-generated content; $\left({ }^{\star}\right) 5.16$ is the mean value of trust with information provided by other travellers in social media; $\left({ }^{\star \star}\right)$ Measured on a seven-point Likert scale where $1=$ strongly disagree, 7 = strongly agree; $\left.{ }^{(\star \star}\right) p<0.05$

UGC had significant differences $(p<0.05)$ in the mean scores from that of third-party tourism communities. Some interviewees also concurred with such result; for example, the information on third-party tourism communities like Mafengwo and Qiongyou was considered the most reliable: "I most trust Mafengwo because information posted by other tourists is not for business profits and is more real" (R3).

PAGE $12 \mid$ JOURNAL OF TOURISM FUTURES $\mid$ VOL 


\section{Discussion}

\section{Diversification of demand-and-supply pattern of social media}

The research findings identified the pattern of social media usage in China, pinpointing to the travel planning process of tourists, and the resultant possibilities of tourism development futures connecting to smartness and innovativeness. Given a rapid development and vigorous usage of social media in China (CTA and Ctrip, 2017; Luo and Zhai, 2017), a great variety of online platforms were established in mainland China which facilitate more diversified functions of information provision and social networking. Such supply-side advancement also triggered multiple channels of social media usage on the demand side. This trend was particularly apparent amongst female and highly educated user segments in the travel process, who at least used different social media tools twice or more during each journey.

The selection and usage of specific types of social media are determined by the functions offered. Some social media apps were mostly confined to more specialized functions; for example, information search by Ctrip; travel reviews by Mafengwo and Dazhongdianping; experience and narrative sharing by WeChat, Weibo and $\mathrm{QQ}$; and more generic factual platforms like Baidubaike. A clear provision of travel-related functions was well-established and defined by users. However, this research confirmed that Chinese tourists tend to install and utilize a number of social media simultaneously (Table 4) rather than picking up one or very few apps.

Moreover, multi-functional social media platforms were more acceptable by Chinese users. According to both survey and in-depth interviews, these platforms such as WeChat were predominantly used in travel planning process, especially in the pre-trip stage for product identification and information search as revealed by Cox et al. (2009). WeChat is popular for these searching functions in addition to its traditional communication app since WeChat has successfully transformed from a socializing software to a lifestyle-oriented platform, which penetrates into many areas in the communities such as public payments, online shopping, medical treatment and travel booking. Nevertheless, this study does not concur with the suggestion of Fotis et al. (2011) that it is a dominant travel-related app of social media in post-trip stage. In China, users prefer an app with social networking function embedded, which was also discovered in Chen (2017).

\section{Functions and influences of China's social media on travel planning process}

Regarding the usage of social media, the PCA results show that the common social media platforms in China were used for two purposes: search for travel information and sociability function. However, such two-fold functionality does not exist clearly across the three stages of the travel process. The influences of social media on individual travel planning could be identified. During the trip, tourists particularly need to search for information about specific attractions and leisure activities (Factor 1) and communicate with friends and acquaintances, and then connect with other travellers (Factor 2). This observation is therefore coherent with the earlier findings and notions that mainland Chinese tourists tend to accept and welcome multi-functional social media platforms and often combine the use of different apps. The during-the-trip function has been under explored (Liu et al., 2020). This is also in line with the arguments of Xiang and Gretzel (2010) and Boley et al. (2013) on the contribution of social media to tourism futures in the travel information search process by tourists. Correlation analysis confirmed that social media influenced the possibility of subsequent or during-the-trip changes in all different aspects as reported by Fotis et al. (2011). Such influence of social media is in turn also moderately affected by varied levels of trust amongst different platforms or apps.

The level of trust across different platforms and usage pattern is an important issue in China supported by the empirical findings. Online UGC cannot effectively replace WOM supplied by the people known to the users (Fotis et al., 2011). The level of trust across different types of social media depends on particular functions (Munar and Jacobsen, 2013). For example, third-party tourism communities such as Mafengwo, Zhihu, Xiaohongshu and Dazhongdianping were regarded as reliable sources of travel information due to a collection of online ratings, reviews and 
comments altogether on a platform (Porter, 2004). Microblogs and blogs were relatively less trusted by users as they must conduct more information mining and consolidation before deciding. Baidubaike as one of collaborative projects was the least trusted since it was difficult for experienced visitors to verify the information accuracy. Travel-related websites provided by tourism industries were identified as trustworthy by Cox et al. (2009), but the same result is not supported in the current study.

\section{Conclusion and implications}

This paper demonstrated the case of social media usage in mainland China, which has been regarded as one of the fastest growing and influential tourist-generating markets and social media expansions in the world (CTA and Ctrip, 2017 CNNIC, 2017). Previous studies such as e.g. Shi (2013), Shang (2016) and Chen (2017) provided many pieces of useful references to the social media use pattern in different destinations in China. This study further addressed the knowledge gap by correlating social media usage and travel planning process of Chinese tourists. The research findings suggested diversification of the demand-and-supply pattern of social media users in China, as well as the use of social media as tools before, during and after travel. Users were diversified in terms of their adoption of social media, use behaviour, scope, the levels of trust, influence and the ultimate travel decisions (Munar and Jacobsen, 2013).

\section{Implications to tourism development futures in China}

Given a more fragmented and localized Chinese social media sector (Chiu et al., 2012), further academic studies on the individual influence of social media platforms are necessary. Another valuable knowledge area is the utilization of big data and data mining techniques to study the effect of UGC of social media on tourists' behaviour, innovation and sustainability of destinations (Chan et al., 2019; Luo and Zhai, 2017; Pikkemaat et al., 2019). This is needed to understand how much UGC contributes to various aspects of sustainable tourism futures such as economy, environment, destination image and local communities (Alaei et al., 2019; Fuchs et al., 2014; Lam et al., 2020; Li et al., 2018; Nowacki and Niezgoda, 2020; Qi and Chen, 2019).

In terms of policy recommendations for urban destinations or practical implications in tourism industries, first, some tactics for specific user segments should be carefully observed. When promoting specific tourism products to Chinese tourists, it is necessary to distinguish between permitted and prohibited platforms which may be different over time by policy change and also understand the user segmentation between platforms or apps. It is also important to integrate appropriate social media when conduct marketing campaigns in order to attract a higher number of visitors. For instance, DMOs and other tourism marketers should clearly identify the division of social media functions and effectively promote appropriate messages or information on the corresponding platforms (e.g. covert and autonomous sources of agents on social networking sites, microblogs and blogs; direct product-oriented advertising on commercial tourism communities; more user-friendly tools and wise integration of UGC into third-party tourism communities) (Ashworth and Voogd, 1994; Kislali et al., 2020).

Second, the higher level of trust in third-party tourism communities shows the difficulty in destination marketing in a globalized world because tourists are no longer receiving only single channel of information and promotion from DMOs and other tourism industry or communication agencies (Munar and Jacobsen, 2013). However, potential tourists might also search and trust much greater variety of information sources. There appears to be an increasingly uncertain level of trust on information in travel process (Dann, 2002) especially when the tension between social media and WOM becomes stronger (Inversini and Schegg, 2002). The flood of online information may challenge the accuracy and reliability of sources, which require more effective UGC management and integration into larger systems of smart tourism destinations (Chan et al., 2019). Tourism development futures require smartness of destinations that provokes more complicated attributes of information usage and networking. More social scientific studies on how people and

PAGE 14 JOURNAL OF TOURISM FUTURES $\mid$ VOL. . $\mathbf{m}$ NO. ... 
information sources interact would definitely benefit a smarter destination connecting people, place and industry.

Moreover, social media and network contribute to sustainable tourism development in postmodern era of travel and mobility (Sobhanifard and Vaeysi, 2020). Urban destinations such as cities are more well-connected geographically by improved transportation and technologically by smarter ICT and social media (Parra-López et al. , 2011; Sarkar and George, 2018; Yoo et al. , 2011). This research further proved the role of social media in sustainable tourism through the empirical observation of social media diversity and usage by tourists (Dinan and Sargeant, 2000; Tiziana et al., 2013). China is one of the most influential outbound market and inbound destinations worldwide. Her social media development and impacts should be examined from a demandsupply perspective (Jamal and Budke, 2020; Moscardo, 2020).

\section{Research limitations}

The linkage between ICT development, social media usage and sustainable practices in tourist destinations still deserves further investigation. This study has yet explored this area of information from the empirical findings but paved the way of this potential research area. Further studies should be conducted to understand, for example, the influence of the use of social media on the changing behavioural intention or actual activities by visitors in destinations. How the use of social media may induce more socially and environmentally conscious by visitors is a potential research question to be answered. More in-depth examination should be performed to test the applicability of the theoretical model developed, for example, through quantitative analysis of big data and the comparison between destinations and countries.

This study also faced methodological and practical limitations including constraints in sampling scale, sampling method and interpretations of interviews. The sampled survey respondents might not comprehensively represent the large number of Chinese tourists although the online questionnaire was distributed to all the Chinese social media platforms in this study to collect a more diversified user profile. There were only seven interviewees who had agreed to participate in the online interviews, and consequently, the sample size might not represent a comprehensive picture of the phenomenon. Nevertheless, the follow-up interviews aimed to provide supplementary information about the perceived use of social media and its influence on destination image of the survey respondents. Finally, the interview responses and the corresponding information in the analysis might have been determined by researchers' interpretations and thus carried a degree of subjectivity. It is therefore an opportunity for more vigorous and further in-depth research about the perception and sentiment analysis of these social media users.

\section{References}

Akehurst, G. and Akehurst, G. (2009), "User generated content: the use of blogs for tourism organisations and tourism consumers", Service Business, Vol. 3 No. 1, pp. 51-61.

Alaei, A.R., Becken, S. and Stantic, B. (2019), "Sentiment analysis in tourism: capitalizing on big data", Journal of Travel Research, Vol. 58 No. 2, pp. 175-191.

Ali, A. and Frew, A.J. (2010), "ICT and its role in sustainable tourism development", in Gretzel, U., Law, R. and Fuchs, M. (Eds), Information and Communication Technologies in Tourism, Springer Wien, New York, pp. 479-491.

Amaro, S., Duarte, P. and Henriques, C. (2016), "Travelers' use of social media: a clustering approach", Annals of Tourism Research, Vol. 59, pp. 1-15.

Ashworth, G.J. and Voogd, H. (1994), "Marketing and place promotion”, in Gold, J.R. and Ward, S.V. (Eds), Place Promotion: the Use of Publicity and Marketing to Sell Towns and Regions, Wiley, Chichester, New York, pp. 39-52.

Boley, B.B., Magnini, V.P. and Tuten, T.L. (2013), "Social media picture posting and souvenir purchasing behavior: some initial findings", Tourism Management, Vol. 37, pp. 27-30. 
Brandtzæg, P.B. (2010), "Towards a unified Media-User Typology (MUT): a meta-analysis and review of the research literature on media-user typologies", Computers in Human Behavior, Vol. 26, pp. 940-956.

Buhalis, D. and Law, B. (2008), "Progress in information technology and tourism management: 20 years on and 10 years after the Internet-The state of eTourism research", Tourism Management, Vol. 29 No. 4, pp. 609-623.

Carifio, J. and Perla, R.J. (2007), "Ten common misunderstandings, misconceptions, persistent myths and urban legends about Likert scales and Likert response formats and their antidotes", Journal of Social Sciences, Vol. 3 No. 3, pp. 106-116.

Casaló, L.V., Flavián, C. and Guinalíu, M. (2011), "Understanding the intention to follow the advice obtained in an online travel community", Computers in Human Behavior, Vol. 27 No. 2, pp. 622-633.

Chan, N.L. and Guillet, B.D. (2011), "Investigation of social media marketing: how does the hotel industry in Hong Kong perform in marketing on social media websites?", Journal of Travel and Tourism Marketing, Vol. 28 No. 4, pp. 345-368.

Chan, C.S., Peters, M. and Pikkemaat, B. (2019), "Investigating visitors' perception of smart city dimensions for city branding in Hong Kong", International Journal of Tourism Cities, Vol. 5 No. 4, pp. 620-638.

Chen, D.L. (2017), 社交媒体营销对旅游者决策行为的影响研究 [Research on the Influence of Social Media Marketing on Tourists' Decision-Making Behavior], Working Paper, Humanities and Media School, Ningbo University, Ningbo.

Chiu, C., Ip, C. and Silverman, A. (2012), "Understanding social media in China”, The McKinsey Quarterly, No. 2, p. 78.

Choe, Y., Kim, J. and Fesenmaier, D.R. (2017), "Use of social media across the trip experience: an application of latent transition analysis", Journal of Travel and Tourism Marketing, Vol. 34 No. 4, pp. 431-443.

Chong, A.Y.L., Khong, K.W., Ma, T., McCabe, S. and Wang, Y. (2018), "Analyzing key influences of tourists' acceptance of online reviews in travel decisions", Internet Research, Vol. 28 No. 3, pp. 564-586.

CNNIC (2017), "The 40th statistical report on internet development in China (report No 40)", available at: https://cnnic.com.cn/IDR/ReportDownloads/201807/P020180711387563090220.pdf (accessed 01 June 2018).

Cox, C., Burgess, S., Sellitto, C. and Buultjens, J. (2009), "The role of user-generated content in tourists' travel planning behavior”, Journal of Hospitality Marketing and Management, Vol. 18 No. 8, pp. 743-764.

CTA and Ctrip (2017), "2017 China outbound tourism big data report", available at: https://baijiahao.baidu. $\mathrm{com} / \mathrm{s}$ ?id $=1593705862773203628 \& \mathrm{wfr}=$ spider\&for $=$ pc.

Dancey, C.P. and Reidy, J. (2011), Statistics without Maths for Psychology, 5th ed., Prentice-Hall, Harlow, New York.

Dann, G. (2002), Tourist as a Metaphor of the Social World, CABI Publishing, Wallingford.

Dao, D.V. (2015), "Social media classification scheme in online teaching and learning activities: a consideration for educators", International Journal of Education and Social Science, Vol. 2 No. 4, pp. 85-94.

Derlega, V.J. and Grzelak, J. (1979), "Appropriateness of self-disclosure”, in Chelune, G.J. (Ed.), Selfdisclosure: Origins, Patterns, and Implications of Openness in Interpersonal Relationships, Jossey-Bass, San Francisco, pp. 151-176.

Dinan, C. and Sargeant, A. (2000), "Social marketing and sustainable tourism: is there a match?", International Journal of Tourism Research, Vol. 2 No. 1, pp. 2-14.

Dinnie, K. (2011), City Branding: Theory and Cases, Palgrave Macmillan, London.

Filieri, R., Alguezaui, S. and McLeay, F. (2015), "Why do travelers trust TripAdvisor? Antecedents of trust towards consumer-generated media and its influence on recommendation adoption and word of mouth", Tourism Management, Vol. 51, pp. 174-185.

Filo, K., Lock, D. and Karg, A. (2015), "Sport and social media research: a review", Sport Management Review, Vol. 18 No. 2, pp. 166-181.

Fotis, J., Buhalis, D. and Rossides, N. (2011), "Social media impact on holiday travel planning: the case of the Russian and the FSU markets", International Journal of Online Marketing (IJOM), Vol. 1 No. 4, pp. 1-19. 
Fuchs, M., Höpken, W. and Lexhagen, M. (2014), "Big data analytics for knowledge generation in tourism destinations-A case from Sweden”, Journal of Destination Marketing and Management, Vol. 3 No. 4, pp. 198-209.

Ge, J. and Gretzel, U. (2018), "A new cultural revolution: chinese consumers' internet and social media use", in Sigala, M. and Gretzel, U. (Eds), Advances in Social Media for Travel, Tourism and Hospitality: New Perspectives, Practice and Case, pp. 102-118.

Goffman, E. (1959), The Presentation of Self in Everyday Life, Doubleday, Garden City, NY.

Gretzel, U. (2018), Tourism and Social Media, The Sage Handbook of Tourism Management, Sage, Los Angeles.

Gretzel, U., Kang, M. and Lee, W. (2008), "Differences in consumer-generated media adoption and use: a cross-national perspective", Journal of Hospitality and Leisure Marketing, Vol. 17 Nos 1-2, pp. 99-120.

Guillet, B.D., Kucukusta, D. and Liu, L. (2016), "An examination of social media marketing in China: how do the top 133 hotel brands perform on the top four Chinese social media sites?", Journal of Travel and Tourism Marketing, Vol. 33 No. 6, pp. 783-805.

Guzzo, T., D’Andrea, A., Ferri, F. and Grifoni, P. (2013), "A framework to promote and develop a sustainable tourism by using social media", in Demey, Y.T. and Panetto, H. (Eds), On the Move to Meaningful Internet Systems: OTM 2013 Workshops, Springer, Berlin, Heidelberg, pp. 656-665.

Haiyan, C. (2010), "An impact of social media on online travel information search in China", 2010 3rd International Conference on Information Management, Innovation Management and Industrial Engineering, Vol. 3, pp. 509-512.

Han, W., McCabe, S., Wang, Y. and Chong, A.Y.L. (2018), "Evaluating user-generated content in social media: an effective approach to encourage greater pro-environmental behavior in tourism?", Journal of Sustainable Tourism, Vol. 26 No. 4, pp. 600-614.

Huang, Y., Basu, C. and Hsu, M.K. (2010), "Exploring motivations of travel knowledge sharing on social network sites: an empirical investigation of US college students", Journal of Hospitality Marketing and Management, Vol. 19 No. 7, pp. 717-734.

Inversini, A. and Schegg, R. (2002), "Information and communication technologies in tourism 2016", Proceedings of the International Conference in Bilbao, Spain, Springer, February 2-5, 2016.

Jamal, T. and Budke, C. (2020), "Tourism in a world with pandemics: local-global responsibility and action", Journal of Tourism Futures, Vol. 6 No. 2, pp. 181-188.

Jeng, J. and Fesenmaier, D.R. (2002), "Conceptualizing the travel decision-making hierarchy: a review of recent developments", Tourism Analysis, Vol. 7 No. 1, pp. 15-32.

Kaplan, A.M. and Haenlein, M. (2010), "Users of the world, unite! the challenges and opportunities of social media", Business Horizons, Vol. 53 No. 1, pp. 59-68.

Kirilenko, A.P., Stepchenkova, S.O. and Hernandez, J.M. (2019), "Comparative clustering of destination attractions for different origin markets with network and spatial analyses of online reviews", Tourism Management, Vol. 72, pp. 400-410.

Kislali, H., Kavaratzis, M. and Saren, M. (2020), "Destination image formation: towards a holistic approach", International Journal of Tourism Research, Vol. 22 No. 2, pp. 266-276.

Kristensen, A.E. (2013), "Travel and social media in China: from transit hubs to stardom", Tourism Planning and Development, Vol. 10 No. 2, pp. 169-177.

Lam, J.M., Ismail, H. and Lee, S. (2020), "From desktop to destination: user-generated content platforms, co-created online experiences, destination image and satisfaction", Journal of Destination Marketing and Management, Vol. 18, p. 100490.

Leung, D., Law, R., van Hoof, H. and Buhalis, D. (2013), "Social media in tourism and hospitality: a literature review", Journal of Travel and Tourism Marketing, Vol. 30 Nos 1-2, pp. 3-22.

$\mathrm{Li}, \mathrm{X}$. and Wang, Y. (2011), "China in the eyes of Western travelers as represented in travel blogs", Journal of Travel and Tourism Marketing, Vol. 28 No. 7, pp. 689-719.

Li, J., Xu, L., Tang, L., Wang, S. and Li, L. (2018), "Big data in tourism research: a literature review", Tourism Management, Vol. 68, pp. 301-323.

Liu, X., Mehraliyev, F., Liu, C. and Schuckert, M. (2020), "The roles of social media in tourists' choices of travel components", Tourism Studies, Vol. 20 No. 1, pp. 27-48. 
Lo, I.S., Lo, A., McKercher, B., Cheung, C. and Law, R. (2011), "Tourism and online photography”, Tourism Management, Vol. 32 No. 4, pp. 725-731.

Luo, Q. and Zhai, X. (2017), ““I will never go to Hong Kong again!" How the secondary crisis communication of 'Occupy Central' on Weibo shifted to a tourism boycott", Tourism Management, Vol. 62, pp. 159-172.

Mack, R.W., Blose, J.E. and Pan, B. (2008), "Believe it or not: credibility of blogs in tourism", Journal of Vacation Marketing, Vol. 14 No. 2, pp. 133-144.

Moscardo, G. (2020), "The story turn in tourism: forces and futures”, Journal of Tourism Futures, Vol. 7 No. 2, doi: 10.1108/JTF-11-2019-0131.

Munar, A.M. (2011), "Tourist-created content: rethinking destination branding", International Journal of Culture, Tourism and Hospitality Research, Vol. 5 No. 3, pp. 291-305.

Munar, A.M. and Jacobsen, J.K.S. (2013), "Trust and involvement in tourism social media and web-based travel information sources", Scandinavian Journal of Hospitality and Tourism, Vol. 13 No. 1, pp. 1-19.

Murphy, L., Moscardo, G. and Benckendorff, P. (2007), "Using brand personality to differentiate regional tourism destinations", Journal of Travel Research, Vol. 46 No. 1, pp. 5-14.

Narangajavana, Y., Fiol, L.J.C., Tena, M.A.M., Artola, R.A.R. and Garcí, J.S. (2017), "The influence of social media in creating expectations. An empirical study for a tourist destination", Annals of Tourism Research, Vol. 65, pp. 60-70.

Noone, B.M., McGuire, K.A. and Rohlfs, K.V. (2011), "Social media meets hotel revenue management: opportunities, issues and unanswered questions", Journal of Revenue and Pricing Management, Vol. 10 No. 4, pp. 293-305.

Nowacki, M. and Niezgoda, A. (2020), "Identifying unique features of the image of selected cities based on reviews by TripAdvisor portal users", Scandinavian Journal of Hospitality and Tourism, Vol. 20 No. 5, pp. 503-519.

Obar, J.A. and Wildman, S. (2015), "Social media definition and the governance challenge: an introduction to the special issue", Telecommunications Policy, Vol. 39 No. 9, pp. 745-750.

Pabel, A. and Prideaux, B. (2016), "Social media use in pre-trip planning by tourists visiting a small regional leisure destination”, Journal of Vacation Marketing, Vol. 22 No. 4, pp. 335-348.

Pan, B., MacLaurin, T. and Crotts, J.C. (2007), "Travel blogs and the implications for destination marketing", Journal of Travel Research, Vol. 46 No. 1, pp. 35-45.

Park, E., Kang, J., Choi, D. and Han, J. (2020), "Understanding customers' hotel revisiting behaviour: a sentiment analysis of online feedback reviews", Current Issues in Tourism, Vol. 23 No. 5, pp. 605-611.

Parka, S. and Nicolau, J.L. (2015), "Asymmetric effects of online consumer reviews", Annals of Tourism Research, Vol. 50, pp. 67-83.

Parra-López, E., Bulchand-Gidumal, J., Gutiérrez-Taño, D. and Díaz-Armas, R. (2011), "Intentions to use social media in organizing and taking vacation trips", Computers in Human Behavior, Vol. 27 No. 2, pp. 640-654.

Pikkemaat, B., Peters, M. and Chan, C.S. (2018), "Needs, drivers and barriers of innovation: the case of an alpine community-model destination", Tourism Management Perspectives, Vol. 25, pp. 53-63.

Pikkemaat, B., Peters, M. and Bichler, B.F. (2019), "Innovation research in tourism: research streams and actions for the future", Journal of Hospitality and Tourism Management, Vol. 41, pp. 184-196.

Porter, C.E. (2004), "A typology of virtual communities: a mult disciplinary foundation for future research", Journal of Computer Mediated Communication, Vol. 10 No. 1, available at: https://onlinelibrary.wiley.com/ doi/full/10.1111/j.1083-6101.2004.tb00228.x.

Qi, S. and Chen, N. (2019), “Understanding Macao's destination image through user-generated content”, Journal of China Tourism Research, Vol. 15 No. 4, pp. 503-519.

Sarkar, S.K. and George, B. (2018), "Social media technologies in the tourism industry: an analysis with special reference to their role in sustainable tourism development", International Journal of Tourism Sciences, Vol. 18 No. 4, pp. 269-278.

Shang, S.Y. (2016), 社交媒体对成都市青年旅游者决策行为的影响研究 [The Influence of Social Media on Decision-Making Behavior of Young Tourists in Chengdu], Working Paper, School of geography and scientific resources, Sichuan Normal University, Sichuan.

PAGE $18 \mid$ JOURNAL OF TOURISM FUTURES $\mid$ VOL. $\mathbf{m}$ NO. $\mathbf{m}$ 
Shi, H. (2013), Web 2时代下旅游者参与社会网络平台对旅游者旅游决策的影响研究 [Research on the Influence of Tourists' Participation in Social Network Platform on Tourists' Tourism Decision-Making in the Era of Web 2], Working Paper, School of economics and trade, South China University of Science and Engineering, Sichuan, p. 21

Sirakaya, E. and Woodside, A.G. (2005), "Building and testing theories of decision making by travellers", Tourism Management, Vol. 26 No. 6, pp. 815-832.

Sobhanifard, Y. and Vaeysi, M. (2020), "Mixed modeling of the social network mechanisms for the sustainable development of tourism: the case of Iranian Kurdistan", Sustainable Development, Vol. 28 No. 1, pp. 187-196.

Sparks, B.A. and Browning, V. (2011), "The impact of online reviews on hotel booking intentions and perception of trust”, Tourism Management, Vol. 32 No. 6, pp. 1310-1323.

Tang, Y., Zhong, M.L., Qing, F.L., Fang, Y. and He, M.F. (2017), “新媒体在入境旅游目的地营销中的应用一 以四川省为例 [Application of new media in inbound tourism destination marketing - a case study of Sichuan Province]”, 技术与市场 [Skills and Market], Vol. 24 No. 6, pp. 63-67.

Tussyadiah, I.P. and Fesenmaier, D.R. (2009), "Mediating tourist experiences: access to places via shared videos", Annals of Tourism Research, Vol. 36 No. 1, pp. 24-40.

Tussyadiah, I.P., Park, S. and Fesenmaier, D.R. (2011), "Assessing the effectiveness of consumer narratives for destination marketing", Journal of Hospitality and Tourism Research, Vol. 35 No. 1, pp. 64-78.

Wang, Y. and Fesenmaier, D.R. (2004), "Towards understanding members' general participation in and active contribution to an online travel community”, Tourism Management, Vol. 25 No. 6, pp. 709-722.

Wasserman, T. (2006), "Report: consumers don't trust blogs”, Brandweek, Vol. 47 No. 31, p. 10.

Whiting, L.S. (2008), "Semi-structured interviews: guidance for novice researchers", Nursing Standard, Vol. 22 No. 23 , pp. $35-40$

Woodside, A.G. and Lysonski, S. (1989), "A general model of traveler destination choice", Journal of Travel Research, Vol. 27 No. 4, pp. 8-14.

Xiang, Z. and Gretzel, U. (2010), "Role of social media in online travel information search", Tourism Management, Vol. 31 No. 2, pp. 179-188.

Xiang, Z., Du, Q., Ma, Y. and Fan, W. (2017), "A comparative analysis of major online review platforms: implications for social media analytics in hospitality and tourism", Tourism Management, Vol. 58, pp. 51-65.

Yoo, K.H. and Gretzel, U. (2010), "Antecedents and impacts of trust in travel-related consumer-generated media”, Information Technology and Tourism, Vol. 12 No. 2, pp. 139-152.

Yoo, K., Gretzel, U. and Zach, F. (2011), "Travel opinion leaders and seekers", in Law, R., Fuchs, M. and Ricci, F. (Eds), Information and Communication Technologies in Tourism 2011: Proceedings of the International Conference, New York, Springer, pp. 525-535.

Zarezadeh, Z.Z., Rastegar, H.R. and Gretzel, U. (2018), "Reviewing the past to inform the future: a literature review of social media in tourism", Czech Journal of Tourism, Vol. 7 No. 2, pp. 115-131.

Engel, J.F., Kollat, D.T. and Blackwell, R.D. (1973), Consumer Behavior, 2nd ed., Rinehart and Winston, Oxford, Holt.

Tiziana, G., Alessia, D., Fernando, F. and Patrizia, G. (2013), "A framework to promote and develop a sustainable tourism by using social media", International Journal of Tourism Sciences, Vol. 18 No. 4, pp. 269-278.

\section{Author affiliations}

Yuke Yuan is based at the The Chinese University of Hong Kong, Hong Kong, China.

Chung-Shing Chan is based at the Department of Geography and Resource Management, Centre for Environmental Policy and Resource Management (CEPRM), The Chinese University of Hong Kong, Hong Kong, China.

Sarah Eichelberger is based at the University of Innsbruck, Innsbruck, Austria.

Hang Ma is based at the Harbin Institute of Technology Shenzhen, Shenzhen, China.

Birgit Pikkemaat is based at the University of Innsbruck, Innsbruck, Austria. 
About the authors

Yuke Yuan holds a Master's Degree in Social Science in Sustainable Tourism from the Department of Geography and Resource Management at the Chinese University of Hong Kong. Her main research interests include sustainable tourism, social media in tourism and online marketing.

Chung-Shing Chan is an Assistant Professor in the Department of Geography and Resource Management at the Chinese University of Hong Kong. His teaching and research interests include place branding and sustainable tourism. Chung-Shing Chan is the corresponding author and can be contacted at: ccs_johnson@cuhk.edu.hk

Sarah Eichelberger is a Pre-Doc University Assistant in the Department of Strategic Management, Marketing and Tourism at the Faculty of Business and Management, University of Innsbruck. Her research interests include quality of life in tourism, entrepreneurial ecosystems and tourism destinations.

Hang $\mathrm{Ma}$ is a Professor in the School of Architecture and Urban Planning, Harbin Institute Technology Shenzhen Graduate School. Her doctoral research investigates the renovation of traditional heritages in China. Her teaching and research interests include sustainable urban renovation, ecological urban design and architectural design.

Birgit Pikkemaat is an Assistant Professor in the Department of Strategic Management, Marketing and Tourism at the School of Management, University of Innsbruck. Her research interests include the areas of innovation and product development, destination management and small- and medium-sized (family) business.

For instructions on how to order reprints of this article, please visit our website: www.emeraldgrouppublishing.com/licensing/reprints.htm

Or contact us for further details: permissions@emeraldinsight.com 